\title{
Attrition: Exploring Dimensions of Employee Attrition in the IT industry
}

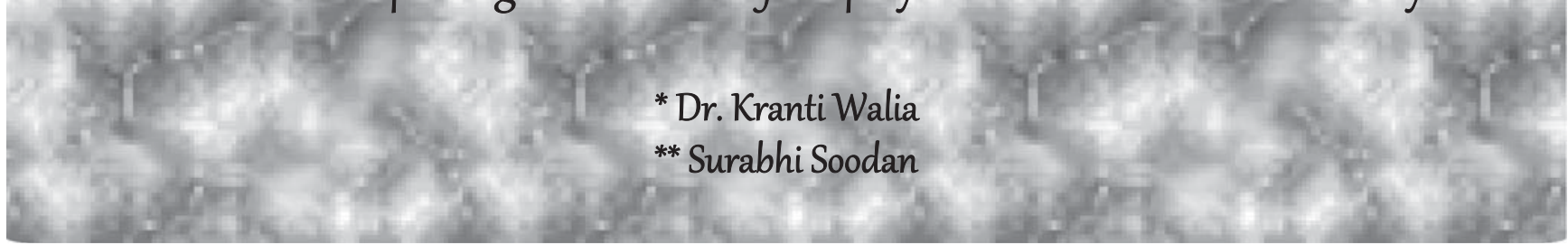

Effulgence

Vol. 13 No. 1

January - June, 2015

Rukmini Devi Institute of Advanced Studies

E-mail : effulgence@rdias.ac.in, Website : www.rdias.ac.in http:/ / effulgence.rdias.ac.in/user/default.aspx

Abstract

https://dx.doi.org/10.33601/effulgence.rdias/v13/i1/2015/64-71

\begin{abstract}
Attrition is acting as biggest challenge in IT industry. This study explores the major factors responsible for determining the attrition in IT industry with special reference to NCR region. It also examines the effects of demographics of the respondent on attrition. A self administered questionnaire was used in this study to collect data on the sampling population. Descriptive analysis, factor analysis, one-way ANOVA, PostHoc test, Welch test and independent sample t-test were used to test the bypothesized propositions. The results showed that there are seven major factors that are responsible for employee attrition in IT industry viz. policy, satisfaction, performance, development, growth, relation and employment. Present study revealed that attrition variables are affected by demographics of the respon dents.
\end{abstract}

Keywords: Attrition, IT industry, satisfaction.

\section{INTRODUCTION}

A ccording to a Hay Group Study, one out of four employees in organized sector in India is set to switch jobs. Employment scenes are changing their appearance on a day to day basis. It has been observed that the factors like skill sets, satisfaction from one's job actually drive the employment and not just the monetary benefits. Absence of such above said factors leads to employee turnover. The employer hence faces the heat of continuous employee turnover. Attrition was $20.3 \%$ in 2010 on an employee base of Rs 64.4 crores. As growth builds and employment opportunities will increase, the number of workers expected to take flight will reach Rs 161.7 million in 2014 - a $12.9 \%$ increase compared with 2012, according to the Hay Group study. For the next five years, it is been predicted that 49 million employees will leave their employers globally. Worldwide, average employee turnover rates are predicted to rise to $23.4 \%$ over the next five years. The number of global departures in 2018 is expected to be at 192 million. Turnover rates are forecast to be higher where market prospects are better. Hence the employees in emerging markets will certainly continue to have wide employment opportunities and be among the first to take flight.
Attrition refers to a natural and gradual reduction in the employees, as through retirement, resignation, or death in any organization (National Performance Review 1997). It means not only there is loss of talented employees, but it also includes the cost of training the new recruited employees. The cause of attrition may be either voluntary or involuntary, though employer-initiated events such as layoffs are not typically included in the definition. There can be a possibility for a company to use employee attrition to its benefit in some circumstances, such as relying on attrition to control the labor costs without declaring massive layoffs.

Continuous efforts are made by organizations to control the employee turnover rate as it directly affects the performance of the organization as many key people leave the organizations for various reasons at crucial point. A huge concern to most companies, employee attrition is a costly expense especially in lower paying job roles, for which the employee attrition rate is highest. Many factors play a role in the employee attrition rate of any company, and these can stem from both the employer and the employees. Wages, company benefits, employee attendance, and job performance are all factors that play a significant role in employee attrition. 
Always, attrition has been considered a very sensitive issue with IT firms. Irrespective of offering the highest salaries across all business segments, IT industry has been plagued with attrition across the board, particularly in the past few years. There are two main issues: ever-growing wage inflation and attrition rates which together keep on putting financial pressures on most of the organizations.

\section{CONCEPTUALIZATION OF HYPOTHESIS}

Numerous researchers have reported a relationship between job satisfaction and thoughts of quitting the job. At first, a model is proposed by Mobley (1977) which explained the relationship between job satisfaction and thoughts of leaving the job which ultimately led to voluntary turnover. According to the paper presented by Mobley et al (1979) demographic variables like age, tenure and overall satisfaction, job content, intentions to remain on the job, and commitment were all inversely related to turnover. It means increase in any one of these variable, led to decrease in the turnover. Costly et al. (1987) explained that a high labour turnover is negatively related to personnel policies, recruitment policies, supervisory practices, grievance procedures and motivation. These entire factors cause high employee turnover if all these practices are not properly managed may also result in poor grievance procedures.

Hom and Griffeth (1995) conducted a meta-analysis of some 800 attrition studies and recently Griffeth et al, (2000) has updated his study. According to study conducted by him there are some well-established findings on the factors affecting turnover. Factors responsible for turnover include job satisfaction, organisational commitment, comparison of alternatives and intention to quit. Manu et al. (2004) concluded economic reasons are the major reason behind employee turnover. Study is conducted with the help of economic model which emphasis that people left organization due to economic reasons and by the aid of this model labour turnover in the market can be predicted.

Lee (2012) in his study concluded that valid women are more content with their jobs and more prone to turnover may not be valid anymore or may need to be revised. Lyness et.al (2001) described the relationships of Gender, Promotions, and Family Leaves of Absence to Voluntary Turnover. He concluded that female managers' voluntary turnover rates were slightly lower than those of their male counterparts. According to paper published by Blease et.al ( 2005 ) on voluntarily and involuntarily turnover in the presence of controls for firm performance, governance characteristics, and executive human capital is more likely to be in females.
Aondoaver Ucho et.al (2012) explored the relationship between job satisfaction, gender, tenure, and turnover intentions.The analysis confirmed that job satisfaction was negatively related to turnover intentions. The results also showed that gender and job tenure were not significant factors in turnover intentions. Brown et al (1995) identifies Gender Differences in Faculty Turnover through his research. He concluded that faculty women in aggregate have higher turnover than faculty men and tenure system positions is the key to reduce female turnover.

In present study, the following hypotheses have been formulated:

$\mathbf{H}_{\text {o }}$ (1) Gender of the respondents is significantly related with the different factors that affect the voluntary turnover.

$\mathbf{H}_{\mathrm{o}}$ (2) Tenure of the respondents is significantly related with the different factors that affect the voluntary turnover.

\section{OBJECTIVES OF THE STUDY}

- The main objective of the present study is to explore the major factors responsible for determining the attrition in IT industry with special reference to NCR region.

- To determine whether the attrition variables are affected by the demographics of the respondents.

\section{RESEARCH METHODOLOGY}

\section{LOCALE OF THE STUDY}

In the present study, the population comprised of employees working in various IT companies in the National Capital Region. Respondents were the employees of these companies who had actually left the organization voluntarily and the superannuated employees. The respondents were identified and contacted with the help of their personal files available with the company. This study was conducted in 2013 in the month of July and August.

\section{SAMPLING AND THE SAMPLE SIZE}

A descriptive study was conducted to achieve the objectives. Judgmental sampling method was followed to collect the relevant data. The sample size chosen for this study was 100 as the respondents in the study were those who had left their organization. Data was collected by making personal visits to them or through mails. 


\section{SURVEY INSTUMENT}

Well-structured questionnaire was developed for conducting the study. Questionnaire had two sections. First section contained questions regarding demographic profile of the respondents while second section contained a list of 17 statements pertaining to various variables responsible for voluntary turnover. These variables and statements were collected from literature review. Respondent has to just tick one parameter of each statement depending on whether respondent feel that he is "strongly agree (score 1)", "agree (score 2)", "neutral (score 3)", "disagree (score 4)", or "strongly disagree (score 5)" with the statement. Low mean score implies that respondents are favoring that particular statement.

\section{RESPONDENT'S PROFILE}

A total of 100 questionnaires were distributed for the data collection. Males (78) and females (22) were the representation in the total sample .Majority of the respondents $(55 \%)$ were the respondents in the group of 2 4 years of Tenure and $(28 \%)$ of the respondents were in the group 0-2 years of Tenure. Only (17\%) of the respondents were having more than 4 years of Tenure in their respective company.

\section{Table 1 Demographic profile}

\begin{tabular}{|c|c|c|c|}
\hline & & Frequency & Percent \\
\hline \multirow[t]{4}{*}{ Valid } & More than 4 years & 17 & 17.0 \\
\hline & 2-4 years & 55 & 55.0 \\
\hline & $0-2$ years & 28 & 28.0 \\
\hline & Total & 100 & 100.0 \\
\hline
\end{tabular}

\begin{tabular}{|ll|c|c|}
\multicolumn{4}{c}{ sex } \\
\hline & & Frequency & Percent \\
\hline Valid & male & 78 & 78.0 \\
& female & 22 & 22.0 \\
& Total & 100 & 100.0 \\
\hline
\end{tabular}

\section{DATA ANALYSIS}

In order to determine the major factors responsible for determining the attrition in IT industry factor analysis is used. Factor analysis is a good way of identifying latent or underlying factors from an array of seemingly important variables. In a more general way, factor analysis is a set of techniques, which, by analyzing correlations between variables, reduces their number into fewer factors, which explain much of the original data, more economically. (Nargundkar, 2005).

\section{Table-2 KMO and Bartlett's Test}

\begin{tabular}{|lll|}
\hline \multicolumn{2}{l}{ Kaiser-Meyer-Olkin Measure of } & .555 \\
Sampling Adequacy. & & \\
Bartlett's Test of & Approx. Chi-Square & 408.542 \\
Sphericity & df & aa \\
& Sig. & .000 \\
\hline
\end{tabular}

(Source: survey conducted by researcher)

Measures of Sample Adequacy such as Bartlett's test of spherecity (approx chi-square is 408.542 , degree of freedom is 136 , significance is 0.000$)$ and $\mathrm{KMO}$ value $(0.555)$ showed that data were fit for factor analysis. Principal Component analysis along with Varimax rotation method was used for extracting factors and seven factors were retained on the basis of Eigen values and variance explained. Table- 2 shows the total variance explained in the extracted factors. In total, seven factors have been extracted which cumulatively explained $70.560 \%$ of the total variance.

\section{Table-3 Total Variance Explained}

Rotation Sums of Squared Loadings

\begin{tabular}{|l|l|l|l|}
\hline Component & Total & \% of Variance & Cumulative \% \\
\hline 1 & 2.131 & 12.534 & 12.534 \\
2 & 2.110 & 12.412 & 24.945 \\
3 & 1.826 & 10.738 & 35.684 \\
4 & 1.549 & 9.115 & 44.798 \\
5 & 1.544 & 9.081 & 53.880 \\
6 & 1.521 & 8.947 & 62.827 \\
7 & 1.315 & 7.733 & 70.560 \\
\hline
\end{tabular}

Extraction Method: Principal Component Analysis.

(Source: survey conducted by researcher)

All the statements with factor loadings greater than 0.40 were considered in the corresponding factor. The name of the factors, variable labels and factor loadings are summarized in Table-3. It clearly depicts that Factor 1 is linear combination of variable number 3, 8and 12. Factor 2 is linear combination of variable number 15, 16 and 17 . Factor 3 is linear combination of variable number 5,4 and 11. Factor 4 is linear combination of variable number 9 and 7. Factor 5 is linear combination of variable number 14 and 10. Factor 6 is linear combination of variable number 1 and 
2. Factor 7 is linear combination of variable number 13 and 6. After the number of extracted factors is decided, the next task is to interpret and name the factors. This is done by the process of identifying the factors that are associated with which of the original variables.

Table -4 Rotated Component Matrix

\begin{tabular}{|c|c|c|c|c|c|c|c|}
\hline \multicolumn{8}{|c|}{ Component } \\
\hline & 1 & 2 & 3 & 4 & 5 & 6 & 7 \\
\hline 3. Input for career growth & .844 & & & & & & \\
\hline 8. Incentive system was fair & .829 & & & & & & \\
\hline 12. Effectively occupied & .792 & & & & & & \\
\hline 17. Overall satisfied & & .829 & & & & & \\
\hline 16. Like to join their Organization again. & & .804 & & & & & \\
\hline 15. Recommend their Group. & & .688 & & & & & \\
\hline 5. Identify and utilize the potential & & & .752 & & & & \\
\hline 4. Interesting and challenging work. & & & .748 & & & & \\
\hline 11. Job rotation & & & .649 & & & & \\
\hline 9. Supervisors were cooperative and helpful & & & & .807 & & & \\
\hline 7. Experience added value to me. & & & & .788 & & & \\
\hline 14. Personal training and development. & & & & & .837 & & \\
\hline 10. Enough learning opportunities & & & & & .792 & & \\
\hline 2. Professional relation & & & & & & .861 & \\
\hline 1. Job description & & & & & & .789 & \\
\hline 13. Best use of employee skills & & & & & & & .855 \\
\hline 6. Good use of my skill and abilities. & & & & & & & .695 \\
\hline
\end{tabular}

Extraction Method: Principal Component Analysis.

Rotation Method: Varimax with Kaiser Normalization.

A. Rotation converged in 7 iterations.

(Source: survey conducted by researcher)

All the factors have been given appropriate names according to the variables that have been loaded on each factor. These seven factors are as follows:

\section{Factor-1: Policy}

The rotated matrix has revealed that respondents have perceived this factor to be the most important factor with the highest explained variance of $12.534 \%$. Three out of seventeen variables load on significantly to this factor. This factor has been named as Policy as it includes statements like input for career growth, incentive system was fair and effectively occupied for most of the times.

\section{Factor-2: Satisfaction}

It has been revealed that the second most important factor with explained variance of $12.412 \%$ and three statements were loaded on to this factor. This factor has been named as Satisfaction as it includes statements like Wish to join their organization again, Recommend their organization and overall satisfied.

\section{Factor-3: Performance}

Three types of features load on this factor and together account for $10.738 \%$ of the variance. This factor includes 
statements like identify and utilize the potential, interesting and challenging work and job rotation.

\section{Factor-4: Development}

It was decided to name the grouping of attributes like experience added value to me and supervisor being cooperative together as these both factors are essential components in employee development. They together explained $9.115 \%$ of the variance.

\section{Factor-5: Growth}

The attributes learning opportunities and Training and development correspond to the growth of employees in the organization. Therefore it was termed as "Growth Factor" with $9.081 \%$ of variance.

\section{Factor-6: Relation}

The rotated matrix has revealed that respondents have perceived this factor to be the last but one important factor with the explained variance of $8.947 \%$. This factor includes statements like during my tenure my job description was clear to me and I had very good professional relationship with my immediate reporting manager. Therefore the factor was termed as "Relation Factor".

\section{Factor-7 : Employment}

Two types of features load on this factor and together account for $7.197 \%$ of the variance. The factor includes statements like I was able to make good use of my skill and abilities and The organization made the best use of employee skills to achieve its goal.

To check the normality of the data, One-Sample Kolmogorov-Smirnov Test was conducted as presented in Table-4. It was found that Asymp. Sig value is greater than .05 for all the factors, hence the data is normal to apply any parametric test.

\section{Effect of Gender}

For achieving the objective that whether the attrition variables are affected by the demographics of the respondents, null hypothesis is framed and tested i.e. 'there is no significant relationship between the Demographic variables and the factors'. Independent Sample Test was used to find the effect of gender on the factors as there were two categories to compare. Mean score was calculated for factors where significant relationship between independent and dependent variables (Factors) was observed.

\section{Table-5 Independent Sample Test between Gender and Factors of Attrition}

Equal variances assumed

\begin{tabular}{|c|c|c|c|c|c|c|}
\hline & \multicolumn{2}{|c|}{$\begin{array}{l}\text { Levene's Test for } \\
\text { Equality of Variances }\end{array}$} & \multicolumn{4}{|c|}{ T-test for Equality of Means } \\
\hline & $\mathrm{F}$ & Sig. & $\mathrm{T}$ & Df & Sig. (2-tailed) & Mean Difference \\
\hline Policy & .304 & .583 & 2.440 & 98 & .017 & .5747084 \\
\hline Satisfaction & .057 & .812 & -.387 & 98 & .700 & -.0937276 \\
\hline Performance & .377 & .541 & -.728 & 98 & .468 & -.1761913 \\
\hline Development & 1.017 & .316 & -1.381 & 98 & .170 & -.3318169 \\
\hline Growth & .870 & .353 & -2.425 & 98 & .017 & -.5715900 \\
\hline Relation & .454 & .502 & 1.323 & 98 & .189 & .3181374 \\
\hline Employment & .077 & .782 & -.656 & 98 & .513 & -.1588786 \\
\hline
\end{tabular}

(Source: survey conducted by researcher)

Table-6 Descriptive Mean Score of factors

\begin{tabular}{|l|l|l|l|l|l|}
\hline & Sex & N & Mean & Std. Deviation & Std. Error Mean \\
\hline Policy & male & 78 & .1264359 & .96153076 & .10887192 \\
& Female & 22 & -.4482726 & 1.02684304 & .21892367 \\
Growth & male & 78 & -.1257498 & .95268439 & .10787027 \\
& Female & 22 & .4458402 & 1.05802572 & .22557184 \\
\hline
\end{tabular}

(Source: survey conducted by researcher) 
Null hypothesis HO (1) is partially rejected as it expounds that there is a significant relationship between the views of males \& females on two factors: Growth and Policy. From the descriptive analysis it is evident that the females are giving more importance to policy ( $\mathrm{M}=-.448, \mathrm{SD}=1.026)$ conditions; ( $\mathrm{t}=2.44$., $\mathrm{p}<0.05$ ) whereas males have given higher importance to growth(M=-.125, $\mathrm{SD}=.952)$ conditions; $(t=-2.425, \mathrm{p}<0.05)$. The reasons for this may be that males mostly leave their job for the very basic reason of growth. Females want some specific policies for them in the concern to ensure their survival which they actually could not get and hence become a prominent reason of attrition.

\section{Effect of Tenure}

Whenever we have to compare more than two groups for differences for mean score, one way ANOVA is applied.
One of the assumptions of one way ANOVA is homogeneity of variance, which is checked by Levene test. Levene's test is a measure for the homogeneity of variance among the various categories. Sig values less than 0.05 indicates that the variance among the various categories is not the same. In this case an adjustment to F-test is used which was given by Welch. So, in Table- 8 Sig value of Levene's test was less than 0.05, Welch's Sig values were considered else the usual ANOVA Sig values were taken.

Wherever the significant difference were found, the mean scores were compared to see the responses of the various categories. Further Post hoc analyses were performed wherever independent demographic variable contained more than 2 categories. When there was equal variance among the categories, Tucky's method was used else Games-Howell method was used.(Field 2009)

Table-7 Descriptives

\begin{tabular}{|l|l|l|l|l|}
\hline Performance & $\mathrm{N}$ & Mean & Std. Deviation & Std. Error \\
\hline More than 4 years & 17 & .2831423 & .80653228 & .19561281 \\
2-4 years & 55 & -.2338535 & 1.08557638 & .14637909 \\
0-2 years & 28 & .2874472 & .82260123 & .15545702 \\
Total & 100 & .0000000 & 1.00000000 & .10000000 \\
\hline
\end{tabular}

(Source: survey conducted by researcher)

Table-8 Analysis of Variance between Tenure and factors of Attrition

\begin{tabular}{|l|l|l|l|l|l|l|}
\hline & Levene & Sig. & F & Sig. & Welch & Sig. \\
\hline Policy & 1.88 & 0.16 & 0.09 & 0.91 & 0.54 & 3.67 \\
Satisfaction & 0.29 & 0.75 & 0.62 & & 0.19 & 0.03 \\
Performance & 3.49 & $\mathbf{0 . 0 3}$ & 0.46 & 1.70 & 0.73 & \\
Development & 0.78 & 0.27 & 0.88 & 0.56 & & \\
Growth & 1.32 & 0.17 & 0.58 & & \\
Relation & 1.78 & 0.34 & 0.10 & 0.58 & & \\
Employment & 1.10 & & & & \\
\hline
\end{tabular}

(Source: survey conducted by researcher)

There was no significant difference found in the factors except one factor 'performance'. Post Hoc analysis was employed and Games-Howell method was used for the factor 'performance.' Table-9 reveals that the respondents whose tenure lies between 24 years differ significantly from the respondents having tenure less than 2 years (M.D = .-.5213007 and S.D $=.21352687$ ) and $(p<0.05)$ on the aspects of identification and utilization of the potential of the employees, interesting and challenging work assignments and job rotation as the significant value is less than .05. 
Table-9 Post Hoc Analysis (Multiple Comparisons)

Dependent Variable: Performance

Games-Howell

\begin{tabular}{|l|l|l|l|l|}
\hline (I) tenure & (J) tenure & Mean Difference (I-J) & Std. Error & Sig. \\
\hline More than 4 years & 2-4 years & .5169958 & .24431785 & .101 \\
& 0-2 years & -.0043049 & .24986248 & 1.000 \\
2-4 years & More than 4 years & -.5169958 & .24431785 & .101 \\
& 0-2 years & $-.5213007^{*}$ & .21352687 & .045 \\
$0-2$ years & More than 4 years & .0043049 & .24986248 & 1.000 \\
& 2-4 years & $.5213007^{*}$ & .21352687 & .045 \\
\hline
\end{tabular}

* The mean difference is significant at the .05 level.

(Source: survey conducted by researcher)

\section{FINDINGS}

Factor analysis revealed that there are seven major factors that are responsible for employee attrition in IT industry viz. policy, satisfaction, performance, development, growth, relation and employment. All factors cumulatively explained $70.560 \%$ of the total variance which is considered good in social sciences.

It was found from Independent Sample $\mathrm{t}$-Test that the attrition variables are affected by the demographics of the respondents. There is also a significant difference in mean scores of policy $(\mathrm{M}=-.448, \mathrm{SD}=1.026)$ conditions; $(\mathrm{t}=2.44$., $\mathrm{p}<0.05)$ in case of females and growth $(\mathrm{M}=-.125$, $\mathrm{SD}=.952)$ conditions; $(\mathrm{t}=-2.425, \mathrm{p}<0.05)$ in case of males respectively. Analysis of variance between tenure and factors of attrition concluded that there lies a significant difference in mean scores of three dimensions viz. more than 4 years tenure, 2-4 years tenure and less than 2 years.

Post - Hoc analysis reported a significant difference in mean scores of employees having tenure of less than 2 years and employees having tenure of 2-4 years (M.D = -..5213007 and S.D $=.21352687)$ and $(\mathrm{p}<0.05)$.

\section{CONCLUSION AND DISCUSSION}

"If the job is basically a dead-end proposition, this should be explained before hiring so as not to mislead the employee. The job should be described precisely, without raising false hopes for growth and advancement in the position. Since employees generally want to do a good job, it follows that they also want to be appreciated and recognized for their works. Even the most seasoned employee needs to be told what he or she is doing right once in a while." (Shamsuzzoha, 2007). This finding is indicative of the turnover culture. Any investigation about employees' intentions to leave is always of significance. The present study was undertaken with the objective to determine the major factors responsible for determining the attrition in IT industry majorly in the NCR region. Factor analysis suggests that there are seven factors namely: policy, satisfaction, performance, development, growth, relationship and employment that respondents deem important. They are in accordance with the factors explained by Mobley et al (1979) and Manu et al. (2004).

According to findings of the study the attrition variables are affected by the demographics of the respondents like gender and tenure. Contrary to the expectations, gender was found to be related to two important factors i.e. policy and growth. Previous studies, however, revealed that high turnover is negatively related to personnel policies, recruitment policies, supervisory practices Costly et al. (1987) .Males are most of the times leaving their jobs for the very basic reason of lack of opportunity of advancement and growth. Females have found to be not been satisfied with the policies of the concern like promotion and transfer policies.

Tenure was found to significantly affect performance factor of the attrition. This result is similar to previous findings Mobley et al (1979). When the performance factor was compared across the three tenure groups a significant difference was found between 2-4 years tenure and less than 2 years tenure of the respondents. Employees with less than 2 years job are more likely to leave the job suggesting that they are more career oriented and want to achieve heights promptly .So, they toggle their job whenever they get a 
better alternative. Whereas persons with 2-4 years tenure had already attained stability in their respective jobs and thus are more likely to focus on their job and growth in present company. It is probable that if an employee has been in one job for a long time, he or she starts feeling a need to change his or her job perhaps because so many people are doing so. The message is that senior managers and human resource departments can take advantage of the relationships between such variables as organizational commitment, person-organization fit, job satisfaction, and work stress to decrease the intention to leave. It must be realized that individual factors such as age, gender and education are blocking variables since they cannot be manipulated, meaning that they affect turnover intention but are out of an organization's control. An organization that can retain its human resource efficiently will, in the long run, achieve success and profitability.

\section{LIMITATIONS AND SCOPE FOR THE FURTHER STUDIES}

The study's aims are limited to a few aspects only. Firstly, in the present study very limited variables have been considered for assessing attrition. If more variables are taken into consideration, a better result can be attained. Secondly, the data were cross sectional in nature and self reported. A larger sample size could give better results so some caution is required in generalizing the results to the larger population. It should be noted that the study was conducted in the National Capital Region (NCR) of India. Further research can be conducted in sectors like real estate, hospitality, education etc. where attrition has become a common problem and they also face a high rate of attrition.

\section{REFERENCES}

1. Aondoaver Ucho, Terseer Mkavga and Ike E. Onyishi (2012), 'Job Satisfaction, Gender, Tenure, and Turnover Intentions among Civil Servants', Benue State Institute of Interdisciplinary Business Research VOL 3, NO 11, pp 378-387. [ In text citation: Aondoaver Ucho et.al (2012)]

2. Brown, Byron W., and Stephen A. Woodbury. (1995), 'Gender Differences in Faculty Turnover',Upjohn Institute Working. Kalamazoo, MI: W.E. Upjohn Institute for Employment Research. Paper No. 95-34.[ In text citation Brown et.al (2012)]

3. C. Lalitha (2012), 'Managing employee attrition -the hr role \& challenge' International Journal of Research in Management, Economics and Commerce Volume 2, Issue 11.[ In text citation: Lalitha (2012)]

4. Field, A (2009), 'Discovering statistics using SPSS', Sage Publication, $3^{\text {rd }}$ edition, London, pp- 374. . [ In text citation: Field, A (2009)]

5. Griffeth, R.W., Hom, P.W., \& Gaertner, S. (2000), 'A meta-analysis of antecedents and correlates of employee turnover: update, moderator tests, and research implications for the next millennium', Journal of Management, 26, 463-488. [In text citation: Griffeth et.al (2012)]

6. Karen S. Lyness and Michael K. Judiesch, 'Are Female Managers Quitters? The Relationships of Gender, Promotions, and Family Leaves of Absence to Voluntary Turnover', Journal of Applied Psychology 2001, Vol. 86. No. 6. 1167-1178. [In text citation: Lyness et.al0]

7. Mobley, W. H. (1977), 'Intermediate linkages in the relationship between job satisfaction and employee turnover', Journal of Applied Psychology, 62: 237-240. . [In text citation:Mobley et.al (1977)]

8. Mobley W. H., Griffeth R. W., Hand, H. H. \& Meglino, B. M. (1979), 'Review and conceptual analysis of the employee turnover process', Psychological Bulletin vol. 86 (3), pp.493-522. . [In text citation: Mobleyet.al (1979)]

9. Shamsuzzoha, A. (2007), 'Employee Turnover-a Study of its Causes and Effects',Finland: University of Vaasa. . [n text citation: Shamsuzzoha (2007)]

10. Tae Heon Lee (2012), 'Gender Differences in Voluntary Turnover: Still a Paradox?’,International Business Research Vol. 5, No. 10; 2012, pp. 19-28. [In text citation: Lee(2012)]

11. Zografos, G. (2006), 'Employee Turnover Statistics Remain a Great Tool. Franchising World', 38(1), 36. [In text citation: Zografos (2006)] 